\title{
The Linkages Between Democracy, Terrorism and Foreign Direct Investments in Developed and Developing Countries
}

\author{
Necmettin ÇELIKK (https://orcid.org/0000-0003-0139-7778), İzmir Katip Çelebi University, Turkey; \\ necmettin.celik@ikcu.edu.tr
}

Riza BAYRAK (https://orcid.org/0000-0002-7397-2295), OSTIM Technical University, Turkey;

riza.bayrak@ostimteknik.edu.tr

\section{Gelişmiş ve Gelişmekte Olan Ülkelerde Demokrasi, Terörizm ve Doğrudan Yabancı Yatırımlar Arasındaki İlişkiler}

\begin{abstract}
In this study, the linkages between political dynamics and foreign direct investment inwards to 118 developed and developing countries over the 2002-2017 period were analysed by the System GMM Panel Model to avoid the potential endogeneity problem. Findings indicate that the most vital positive determinant of FDI inwards is trade liberalization or trade openness. Also, there is no statistically significant relationship between countries' democratization and freedom level and FDI inwards. However, terrorism hinders FDI directly, especially in developed countries. Therefore, the decision of foreign investors might mainly depend on economic dynamics, which are related to them and host countries rather than politics.

Keywords

JEL Classification Codes :

\section{Democracy, Political Rights, Civil Liberties, Terrorism, Foreign} Direct Investments, System GMM Panel Model.

C33, D74, F21.

$\ddot{\mathbf{O} z}$

Bu çalışmada, 2002-2017 döneminde 118 gelişmiş ve gelişmekte olan ülkeye yönelik yabancı doğrudan yatırımlarla politik dinamikler arasındaki ilişki, olası bir içsellik sorunundan kaçınmak adına, Sistem GMM Panel Modeli tahmicisine dayalı olarak analiz edilmiştir. Bulgular, bir ülkeye yönelik FDI girişlerinin en güçlü pozitif yönlü belirleyicisinin dış ticaret liberilizasyonu ya da dişa açıklık düzeyi olduğunu göstermektedir. Bununla birlikte, bir ülkenin demokratik gelişmişlik ve özgürlük seviyesiyle o ülkeye yönelik FDI girişleri arasında istatistiksel olarak anlamlı bir ilişkiye rastlanılmamıştır. Ancak, terör olaylarının FDI girişleri üzerinde, özellikle gelişmiş ülkelerde, saptırıcı etkiler yarattığı görülmektedir. Bu açıdan bakıldığında, yabancı yatırımcıların yatırım yeri kararlarında politik belirleyicilerden ziyade kendileri ve yatırım yapacakları ülkelere ilişkin iktisadi belirleyicilerin etkili olduğu anlaşılmaktadır.
\end{abstract}

Anahtar Sözcükler $\quad$ : Demokrasi, Politik Haklar, Sivil Özgürlükler, Terörizm, Doğrudan Yabancı Yatırımlar, Sistem GMM Panel Modeli. 


\section{Introduction}

The lack of domestic savings makes it difficult to finance the physical capital accumulation, which is an important determinant of growth, especially in developing countries according to several studies (Shioji, 2001; Wang, 2002; Pereira \& Roca-Sagales, 2003; Bronzini \& Piselli, 2009; Adams, 2009; Önder et al., 2010; Kottaridi \& Stengos, 2010; $\mathrm{Su} \& \mathrm{Liu}, 2016)$. Thus, foreign direct investments (FDI), which are expected to contribute to economic growth directly (Papanek, 1973; Balasubramanyam et al., 1996; Choe, 2003; Mello, 1999; Berthelemy \& Demurge, 2000; Makki \& Somwaru, 2004; Cuadros et al., 2006; Alguacil et al., 2011; Iamsiraroj \& Ulubaşoğlu, 2015; Bandyopadhyay et al., 2014; Bezic et al., 2016) or indirectly by several channels such as domestic capital accumulation (De Mello, 1999), innovation and technology transfer (Su \& Liu, 2016; Liu, 2008; Fedderke \& Room, 2006; Baldwin et al., 2005; De Mello, 1999; Borensztein et al., 1998; Javorcik, 2004) and foreign trade (Sunde, 2017; Makki \& Somwaru, 2004; Cuadros et al., 2004; Alguacil et al., 2002) are recognized as an alternative economic growth resource in FDI-led Growth Theory.

In other words, FDI inwards contributes to economic growth, especially in host countries, through technology transfer, promotion of domestic investments, and increase in human capital and capital accumulation (Goh et al., 2017). It is seen that many developing countries, which became liberal towards the late 1970s, turned out to be more open to FDI inputs (Mistura \& Roulet, 2019: 6).

FDI inwards, concentrated in developed countries and reached a volume of $\$ 1.3$ Trillion worldwide as of $2018^{1}$, head towards developing countries with the 2008 Financial Crisis. According to UNCTAD data, only $28,1 \%$ of foreign direct investment inwards was directed to developing countries in the early 2000s (in 2002), while 70,1\% were referred to developed countries. As of 2018, the share of foreign investments directed to developed countries decreased to $42,9 \%$, whereas investments directed to developing economies increased to $54,4 \%$. This shows that foreign investments tend to turn to develop countries significantly. Indeed, foreign investment inflow to developing economies seems to rise more than six times from 2002 to 2018.

Considering this situation from a geographical point of view, Asian economies are among the developing economies preferred by FDI with an average share of $68 \%$; the American and African economies follow this with $24 \%$ and $8 \%$, respectively. Besides, in Figure 1, from 2002 to 2018, the most significant change is observed in Asian economies, with increases observed more than five times.

1 According to the data of UNCTADSTAT, foreign direct investment inwards, which were around $\$ 590$ Billion in 2002, reached around \$1.3 Trillion by 2018. 


\section{Figure: 1}

Foreign Direct Investment Inwards in Developing Economies (Million \$)

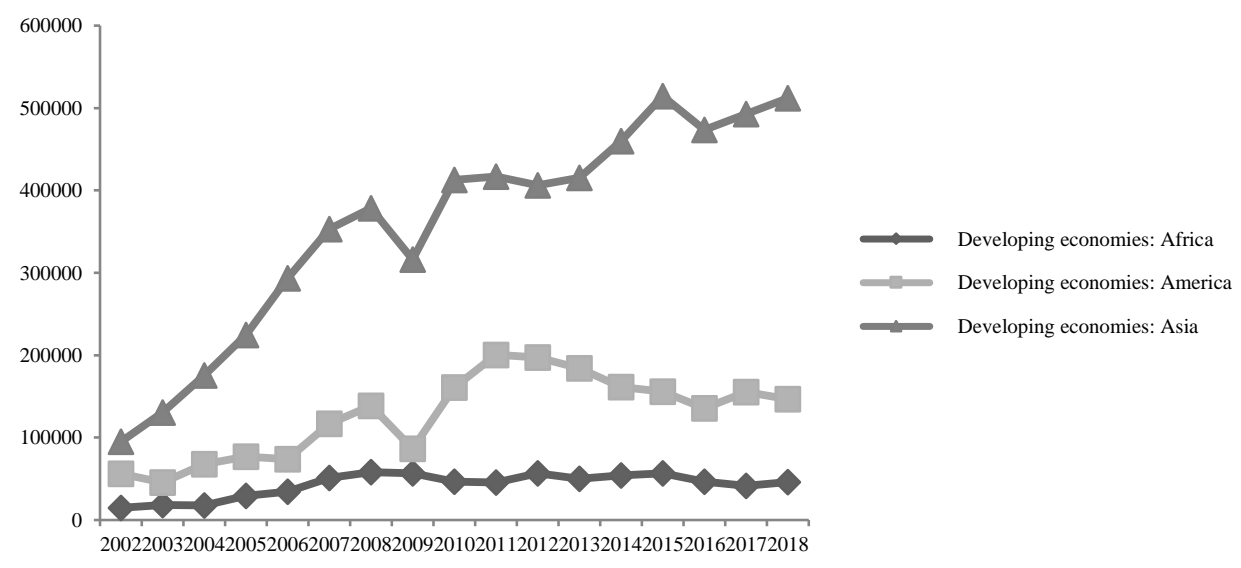

Source: United Nations Conference on Trade and Development (UNCTADSTAT).

Also, in Figure 2, there is a decrease in the capital towards developed European, American, and Asian economies during the crisis years.

Figure: 2

Foreign Direct Investment Inwards in Developed Economies (Million \$)

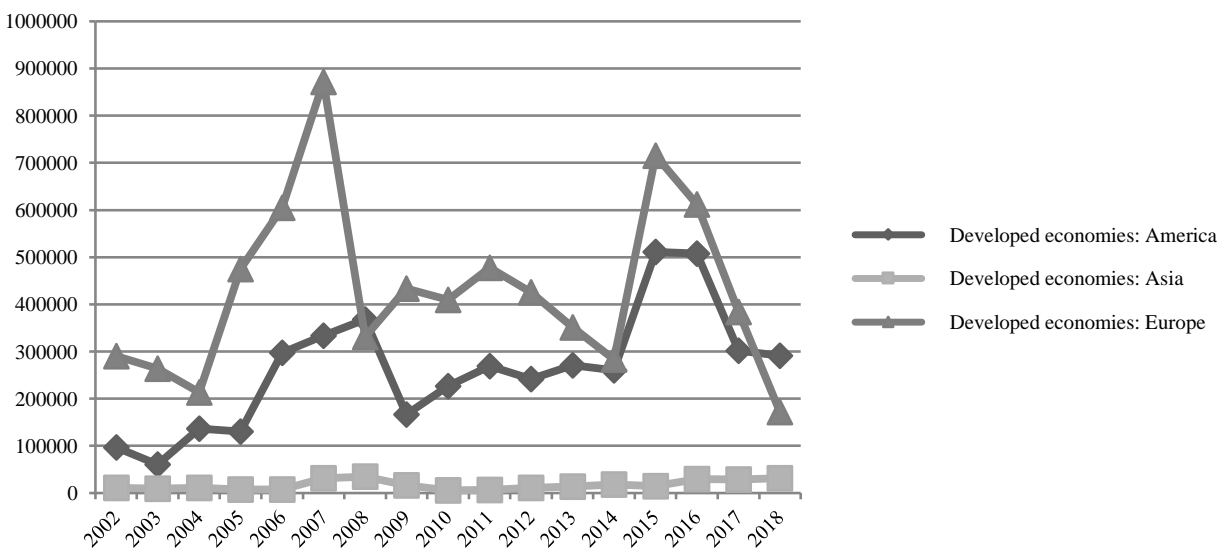

Source: United Nations Conference on Trade and Development (UNCTADSTAT).

Considering the importance of FDI inwards on the economy (UNCTAD, 2004), it is necessary to identify the factors affecting the geographical and local distribution of FDI and 
design policy patterns to provide more FDI entry to especially developing and poor countries.

The theoretical and empirical literature mainly examines the economic determinants of FDI inwards rather than political determinants. Because the perception that FDI inwards acts according to economic factors rather than socio-political factors is widespread in location preferences, in other words, it is evaluated that FDIs do not take into account the socio-political dynamics of countries. In contrast, they act only according to economic dynamics (Busse, 2003: 1).

However, when the spatial distribution of FDI inwards is analysed, it is understood that political dynamics such as democratic development level, political rights, and civil liberties can be the determining factors. Indeed, Figure 3 and Figure 4 show that there is a positive relationship between democracy and FDI, while Figure 5 shows that there is a negative relationship between terrorism and $\mathrm{FDI}^{2}$.

Accordingly, in this study, FDI inwards to 118 developed and developing countries from 2002-2017 were analysed based on the System GMM Panel Estimator. Policy recommendations have been developed according to the findings obtained, especially for developing countries. In this respect, the contribution of this study to the inadequate literature is high.

Figure: 3

The Regional Patterns of FDI Inwards (2015 - Million \$)

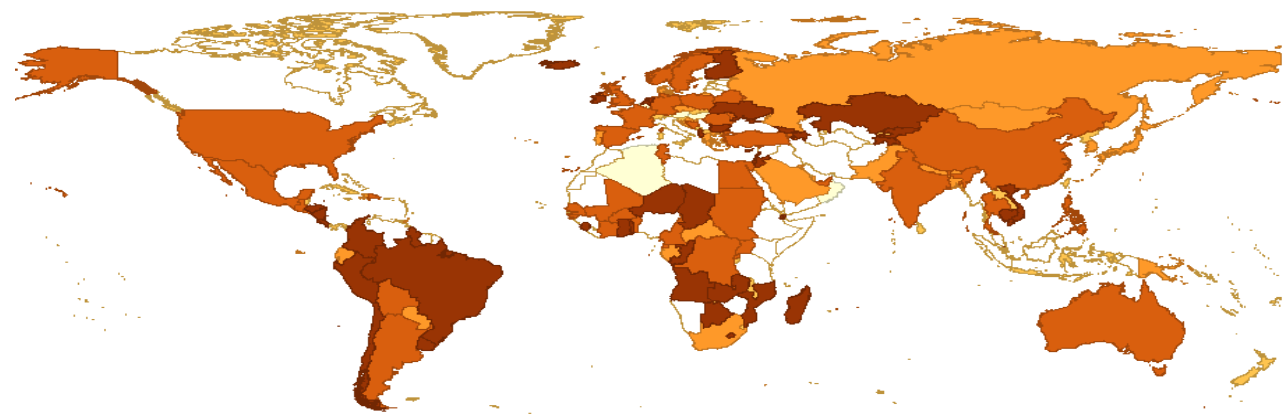

Source: It is compiled from UNCTADSTAT statistics by the Authors.

2 The color darkness degree indicates the higher statistic values. 
Figure: 4

The Regional Patterns of Democratization Values (2015)

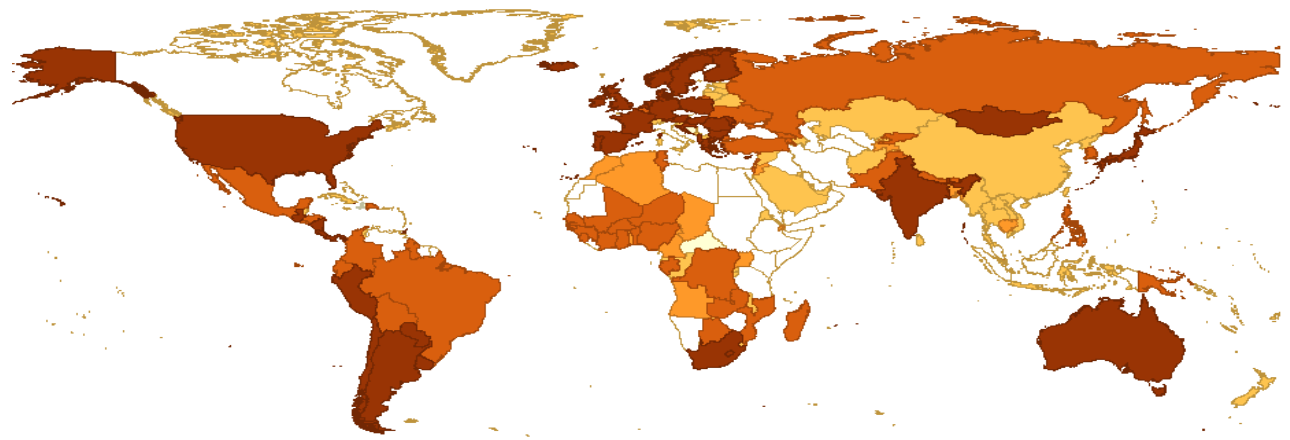

Source: It is compiled from PolityIV statistics by Authors.

Figure: 5

The Regional Patterns of Terrorist Incidents (2015)

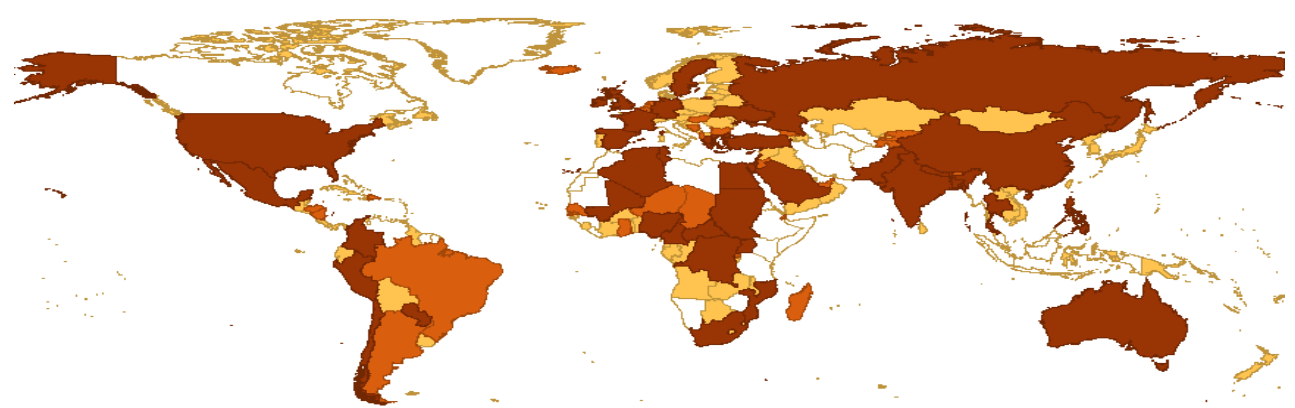

Source: It is compiled from GTD statistics by the Authors.

\section{The Socio-Political Determinants of FDI Inwards}

In literature, democratic development level, political rights, civil liberties, property rights, security and political stability are the main political determinants of FDI inwards.

\subsection{Democracy, Freedom and FDI Inwards}

Democratic development level, political rights, and civil liberties are among the political factors that can effectively affect the geographical distribution of FDI inwards. In an economy, it is emphasized that as civil liberties and democratic values expand, especially economic freedoms which are the basis of intellectual property rights, markets will become more competitive, and economic growth will increase through investments (Feng, 1997; Çelik, 2018). The findings of many studies (Scully, 1988; Grier \& Tullock, 1989; Özler \& Rodrick, 1992; Helliwell, 1994; Alesina \& Perotti, 1994; De Haan \& Siermen, 1996; 
Leblang, 1996; Mbaku \& Kimenyi, 1997; Gupta et al., 1998; Kurzman et al., 2002; Busse 2003; Jensen, 2003; Blume \& Voigt, 2008; Papaioannou \& Siourounis, 2008; Narayan et al., 2011; Cervellatti \& Sunde, 2011; Knutsen, 2013; Qureshi et al., 2015; Çelik \& Karaçuka, 2018) in the literature also show that the direct and/or indirect effects of democracy on growth, through investment patterns, are favourable.

On the other hand, in Figure 6, between $2002-2017^{3}$, it is seen that $69 \%$ of FDI inwards preferred to lead to free countries, while $31 \%$ of them preferred countries that are partially free and not free. On the other hand, in Figure 7, 75\% of FDI inwards seemed to be directed to democratic governments, while $14 \%$ led to anocracy; and only $11 \%$ of them preferred to head to countries with autocratic status ${ }^{4}$. This situation gives a strong impression and supports that foreign investors prefer to lead to free and democratic countries.
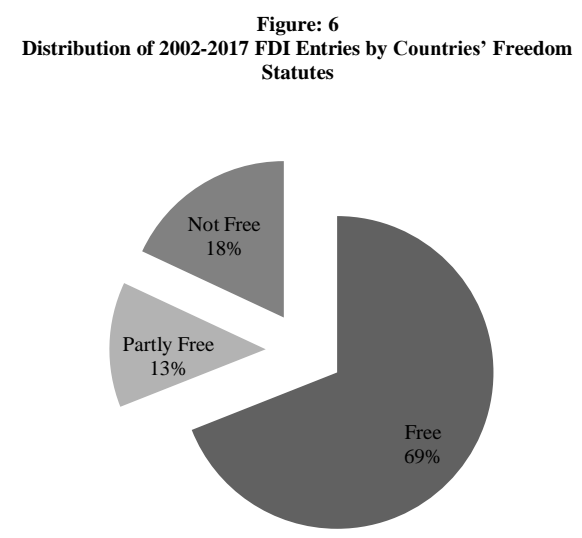

Source: Freedom House
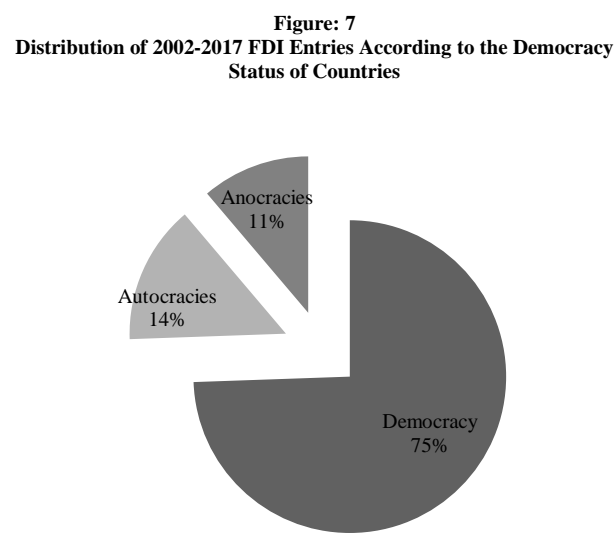

Source: Polity IV Project

\subsection{Political Instability, Uncertainty and FDI's}

Other policy determinants that can be effective in the geographical distribution of FDI inwards are security and political stability. The risk level of investments increases due to the loss of trust when the terrorist attacks reach dramatic levels in a country (Nitsch \& Schumacher, 2004; Enders et al., 2006). Because, besides the direct effects of terrorism, such as loss of life and property, it also can cause negative indirect effects on macro sizes through channels such as investment, tourism, and migration in the medium and long term by damaging the environment of trust and stability. This situation shows that the region's political stability and risk level to be invested are important factors affecting investor decisions (Dunning, 1993; Moosa, 2002). From this point of view, terrorism is one of the

\footnotetext{
3 As of 2002-2017, FDI entries for 118 selected countries include 78,24\% of entries worldwide. It can be said that the dimension of the sample chosen with this aspect is quite strong.

4 The 2017 values of freedom and democracy indices are considered as the base.
} 
important factors that negatively affect FDI inwards (Global Business Policy Council, 2004) by causing a loss of investor confidence (Shahbaz et al., 2013; Bezic et al.). This is based on the Keynesian view that investment decisions can be influenced by psychological factors such as instability and uncertainty and economic and technical factors (Çelik \& Karaçuka, 2018). Indeed, instability and uncertainties may sometimes become more important than market-based indicators such as tax incentives and interest rates (Pindyck, 1991), which may diverge investment decisions (Caballero \& Pindyck, 1992).

The empirical literature suggests a negative relationship between political instability, uncertainty processes, and foreign direct investments. Some studies (such as Schneider \& Frey, 1985; Ender \& Sandler, 1996; Ramcharran, 1999; Blomberg \& Mody, 2005; Enders et al., 2006; Lutz \& Lutz, 2006; Kang \& Lee, 2007; Abadie \& Gardeazabal, 2008; Daniele \& Marani, 2011; Bandyopadhyay et al., 2011; Omay et al., 2013; Filer \& Stanisic, 2016; Rasheed \& Tahir, 2012; Shahbazet al., 201; Kinyanjui, 2014; Ullah \& Rahman, 2014; Ak1nc1 et al., 2015; Bezic et al., 2016; Ali et al., 2017; Saeed et al., 2018; Efobi et al., 2018; Zakaria et al., 2019) support this situation. Besides, Powers and Choi (2012) stated that terrorist attacks targeting multinational companies adversely affect foreign direct investments. In contrast, the attacks that do not target the business world have no significant suppressive effect on FDIs. On the other hand, Bandyopadhyay et al. (2014) found that national terrorist incidents, rather than international terrorist incidents, had a greater divergent impact on FDI inwards.

\section{Figure: 8}

\section{Distribution of FDIs According to the Levels of Countries Affected by Terrorism} (2002-2017)

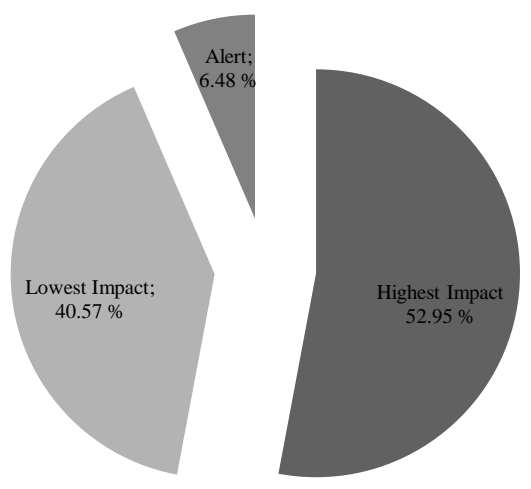

Source: It is compiled from the Global Terrorism Database and UNCTAD Statistics. 
When Figure 8, which shows the FDI distribution in 2002-2017, is analysed, it is seen that the share of FDI to the countries where terrorism is at the alert stage is only $6,4 \%$. This provides impressions that investments tend not to prefer problematic locations with high terrorism risks. On the other hand, only $41 \%$ preferred countries with no terrorism or low effects. However, considering that $53 \%$ of FDI entries are concentrated in countries highly affected by terrorism, it is difficult to maintain the general argument about the FDI's preference for the safe zone 5 .

\section{Methodology and Analysis}

\subsection{Data and Variables}

In this study, the political determinants of foreign direct investment inwards to the 118 countries were analysed over the 2002-2017 period ${ }^{6}$. Table 1 includes detailed information about them. The percentage of net inwards of foreign direct investments in GDP was considered a dependent variable. On the other hand, democracy, civil liberties, political rights, and terrorism were deemed political determinants and control variables, such as GDP per capita, exchange rate, credit amount, and trade openness. Besides, dummy variables estimated by development level were used in alternative econometric models.

Table: 1

\section{The Features of Variables}

\begin{tabular}{|c|c|c|c|c|}
\hline & Abbreviation & Explanation & $\begin{array}{l}\text { Expected } \\
\text { Sign }\end{array}$ & Source \\
\hline $\begin{array}{l}\text { Dependent } \\
\text { Variable }\end{array}$ & FDI/GDP & Foreign direct investment, net inwards (\% of GDP) & & \multirow{5}{*}{$\begin{array}{l}\text { World } \\
\text { Bank }\end{array}$} \\
\hline \multirow{12}{*}{$\begin{array}{l}\text { Independent } \\
\text { Variables }\end{array}$} & CREDITGDP & Domestic credit to the private sector by banks (\% of GDP) & + & \\
\hline & GDPPERCAPITA & GDP per capita (current Million US\$) & + & \\
\hline & EXCHANGERATE & Official exchange rate (LCU per US\$, period average) & + & \\
\hline & OPENNESS & Merchandise trade (\% of GDP) & + & \\
\hline & $D E M O C$ & Democratization values of the countries & + & $\begin{array}{l}\text { Polity } \\
\text { IV }\end{array}$ \\
\hline & $\mathrm{CL}$ & Civil Liberties values of the countries & - & \multirow{2}{*}{$\begin{array}{l}\text { Freedom } \\
\text { House }\end{array}$} \\
\hline & PR & Political Rights values of the countries & - & \\
\hline & TERROR ${ }_{I N C I D E N T S}$ & The total number of terrorist attacks & - & \multirow{3}{*}{ GTD } \\
\hline & TERROR CASUALTIES & The total number of fatalities and injuries due to terrorist attacks & - & \\
\hline & TERROR ${ }_{P R O P E R T Y}$ & The property damage due to terrorist attacks (Million $\$$ ) & - & \\
\hline & DEV_TERROR & $\begin{array}{l}\text { It only includes terrorism indicators of developed countries, respectively, incidents, } \\
\text { casualties, and property; others are equal to } 0 .\end{array}$ & - & \multirow{2}{*}{ Authors } \\
\hline & UNDERDEV_TERROR & $\begin{array}{l}\text { It only includes terrorism indicators of underdeveloped countries, respectively, } \\
\text { incidents, casualties, and property; others are equal to } 0 .\end{array}$ & - & \\
\hline
\end{tabular}

The democracy variable, taken from the Polity IV Database, includes specific weighted forms of the competitiveness of political participation, the openness and

5 As in the GTD classification, countries with GTI values between 8-10 are classified as "alert", those between 4-8 are classified as "highest impact" and those between 0-4 are classified as "lowest impact" (IEP, 2017: 10).

6 The 118 countries that make up the sample represent all countries at a high level in terms of dynamics such as FDI, democracy status, freedom status and terrorism. For example, as of 2017, 78,3\% of FDI entries worldwide are directed towards these countries. In addition, it is seen that the distribution of the sample reflects all countries of the world at a high rate in terms of democracy status, freedom status and terrorism dimension. 
competitiveness of executive recruitment, and constraints on the chief executive. Indeed, it is an eleven-point scale from 0 to 10 representing the most democratic values (Marshall et al., 2013). Countries' civil liberties and political rights values, estimated by 25 indicators such as the electoral process, political pluralism, freedom of expression, and the rule of law, were used as an alternative proxy variable to the democracy variable. They are measured on a one-to-seven scale with one rating representing the freest and seven, the least free conditions (Freedom House, 2018: 3). Therefore, the expected signs of this variable are negative compared to the democracy variable sign.

The total number of terrorist incidents, the total casualties, and property damage due to terrorist attacks was taken into consideration as proxies to estimate frequency degree, human costs, and material costs of terrorism, respectively. These variables could be negative signs since terrorism represents an instability environment for new investments.

On the other side, considering the demand-side and supply-side determinants of foreign direct investments in the empirical literature; GDP per capita; official exchange rate; the percentage of merchandise trade on GDP as trade openness or liberation; and the percentage of domestic credit to the private sector by banks on GDP were used as control variables.

Firstly, the interest rates are the primary determinant of investments as a cost factor. Lower interest rates stand for broader credit advantages and higher profitability. However, host countries' credit amount capacity was considered an alternative financial proxy due to all countries' lack of interest rates data. Indeed, when increasing the credit amount in a country, interest rates, and of course, the costs of investments will decrease thanks to the abundance of money in financial markets. It can also be considered valid for the exchange rate. For instance, by the depreciation of the national currency or appreciation of the foreign currency, investments will decrease. An increase follows this in investments.

Secondly, GDP per capita refers to host countries' purchasing power and demand sustainability. Foreign investors might prefer countries with high purchasing power to establish demand sustainability towards their products. Indeed, economies with larger domestic markets tend to receive more FDI thanks to higher demand (Mistura \& Roulet, 2019).

Finally, trade openness shows the integration degree between the host country and the others; it could positively encourage foreign investors. As the degree of trade openness of a country rises, the exchange of goods between signatory countries will increase. Therefore, trade policies are expected to affect FDI (Mistura \& Roulet, 2019). Consequently, all economic control variables likely get positive coefficients.

\subsection{Econometric Model and Analysis}

System GMM Estimator was used in econometric analysis due to the potential endogeneity problem between foreign direct investment inwards, GDP per capita and 
Exchange rate variables. It covers the 118 countries over the 2002-2017 period. Before the estimation, all variables must be stationarity to avoid spurious regression. Otherwise, $\mathrm{R}^{2}$ and $\mathrm{t}$ statistics could be misleading in this situation, even if the sample is large (Gujarati \& Porter, 2012).

Table: 2

The Results of Panel Unit Root Test (Levin, Lin \& Chu)

\begin{tabular}{|c|c|c|}
\hline Variables & $C$ & $C+T$ \\
\hline CREDITGDP & $-8.0301 * * *$ & $-12.1941 * * *$ \\
\hline GDPPERCAPITA & $-6.2332 * * *$ & $-7.5439 * * *$ \\
\hline EXCHANGERATE & 10.1258 & $-1.7549 * *$ \\
\hline OPENNESS & $-6.7757 * * *$ & $-12.8119 * * *$ \\
\hline$D E M O C$ & 4.2225 & 1.1523 \\
\hline D.DEMOC & 3.8236 & $-18.9615 * * *$ \\
\hline$P R$ & 3.5012 & 2.5574 \\
\hline$D . P R$ & $-2.7093 * * *$ & $-1.5261 *$ \\
\hline$C L$ & 4.9058 & 2.0647 \\
\hline$D . C L$ & 0.1712 & $-21.3125 * * *$ \\
\hline TERROR $_{\text {INCIDENTS }}$ & $-3.5313 * * *$ & $-6.3387 * * *$ \\
\hline TERROR $_{\text {CASUALTIES }}$ & 2.9094 & 0.6482 \\
\hline D.TERROR CASUALTIES & 3.3589 & $-2.2544 * *$ \\
\hline TERROR $P R O P E R T Y$ & $-1.9942 * *$ & $-1.9236 * *$ \\
\hline
\end{tabular}

Note: *,**,*** symbols stand for $\% 10, \% 5$, and $\% 1$ significance level, and $C$ and $C+T$ stands for values with constant and constant + trend, respectively.

According to the results of Levin, Lin, and Chu Panel Unit Root Test presented in

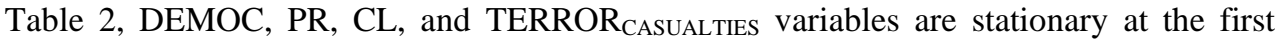
difference; while others are at level. Therefore, the econometric model could be represented as follows:

$$
\begin{aligned}
& \ln \mathrm{FDI}_{i t}=\beta_{1}\left(E_{i t}\right)+\beta_{2}\left(P_{i t}\right)+\beta_{3}\left(D_{i t}\right)+\mathrm{u}_{i t} \\
& \mathrm{i}=1,2, \ldots, 118 \\
& \mathrm{t}=2002,2003, \ldots, 2017
\end{aligned}
$$

where $\mathrm{FDI}_{\mathrm{it}}$ stands for the percentage of net inwards of foreign direct investments in GDP of country $\mathrm{i}$ at period $\mathrm{t}, \mathrm{E}_{\mathrm{it}}$ for a vector of economic determinants of FDI that are CREDITGDP, GDPPERCAPITA, EXCHANGE RATE, and OPENNESS variables; $\mathrm{P}_{\text {it }}$ for a vector of political determinants of FDI that are TERROR INCEDENTS, D.TERROR $_{\text {CASUALTIES, }}$ TERROR ${ }_{\text {PROPERTY }}$, D.DEMOC, and alternatively, D.PR and D.CL variables. Finally, $\mathrm{D}_{\text {it }}$ for a vector of dummy variables that are related development level of countries with terrorism indicators.

\subsection{Findings}

The empirical analysis estimated twelve alternative econometric models using the System GMM Panel Model. Diagnostic results of all models, such as AR (1), AR (2), the number of instruments, Sargan and Hansen Test statistics, are suitable to evaluate the findings as scientifically confidential. According to the results of control variables in all models represented in Table 3 and Table 4, the strongest and positive determinant of foreign 
direct investments is trade liberalization or trade openness. As the trade openness rises $10 \%$, the foreign direct investment inwards to that country increases by $0,4 \%$. On the other hand, GDP per capita and exchange rate are other statistically significant determinants of FDI inwards, although they have nominal size. Finally, findings indicate that there is not any meaningful relationship between domestic credit to the private sector by banks and FDI inwards.

Table: 3

\section{Regression Results (System GMM Twostep)}

\begin{tabular}{|c|c|c|c|c|c|c|c|}
\hline \multicolumn{2}{|l|}{$\begin{array}{l}118 \text { Countries } \\
2002-2017\end{array}$} & $\begin{array}{c}\text { Model } \\
(1)\end{array}$ & $\begin{array}{c}\text { Model } \\
\text { (2) }\end{array}$ & $\begin{array}{c}\text { Model } \\
\text { (3) }\end{array}$ & $\begin{array}{l}\text { Model } \\
\text { (4) }\end{array}$ & $\begin{array}{c}\text { Model } \\
(5)\end{array}$ & $\begin{array}{c}\text { Model } \\
\text { (6) }\end{array}$ \\
\hline \multicolumn{2}{|l|}{ CREDITGDP } & 0.005 & 0.005 & 0.007 & 0.006 & 0.005 & 0.006 \\
\hline \multicolumn{2}{|c|}{ GDPPERCAPITA } & $0.00009^{* * * *}$ & $0.0009 * * *$ & $0.0008^{* * * *}$ & $0.00009^{* * * *}$ & $0.00009^{* * * *}$ & $0.00009^{* * * *}$ \\
\hline \multicolumn{2}{|c|}{ EXCHANGERATE } & $0.0005^{* *}$ & $0.0005 * *$ & $0.005^{* *}$ & $0.0005^{* *}$ & $0.0005^{* *}$ & $0.0005^{* * *}$ \\
\hline \multicolumn{2}{|c|}{ OPENNESS } & 0.04 **** & $0.05^{* * *}$ & $0.04 * * *$ & $0.04 * * *$ & $0.05^{\text {**** }}$ & $0.04 * * *$ \\
\hline \multicolumn{2}{|l|}{ D.DEMOC } & 0.03 & 0.003 & 0.002 & 0.003 & $\mathbf{0 . 0 3}$ & 0.003 \\
\hline \multicolumn{2}{|l|}{ TERRORINCIDENTS } & $-0.001 *$ & & & & & \\
\hline \multicolumn{2}{|c|}{ D.TERROR CASUALTIES } & & 0.00002 & & & & \\
\hline \multicolumn{2}{|c|}{ TERROR PROPERTY } & & & $-0.01 * *$ & & & \\
\hline \multicolumn{2}{|c|}{$D E V_{-} T E R R O R_{I N C I D E N T S}$} & & & & $-0.02 * *$ & & \\
\hline \multicolumn{2}{|c|}{ UNDERDEV_TERROR INCIDENTS } & & & & 0.004 & & \\
\hline \multicolumn{2}{|c|}{ DEV_TERROR CASUALTIES } & & & & & $-0.001 *$ & \\
\hline \multicolumn{2}{|c|}{ UNDERDEV_TERROR_ASUALTIES } & & & & & 0.001 & \\
\hline \multicolumn{2}{|c|}{ DEV_TERROR PROPERTY } & & & & & & $-0.04 * * *$ \\
\hline \multicolumn{2}{|c|}{ UNDERDEV_TERROR RROPERTY } & & & & & & 0.14 \\
\hline \multicolumn{2}{|c|}{ cons. (c) } & -0.15 & -0.22 & -0.15 & -0.17 & -0.24 & -0.19 \\
\hline \multicolumn{2}{|l|}{$\mathbf{A R}(\mathbf{1})$} & $\begin{array}{c}-1.18 \\
{[0.238]}\end{array}$ & $\begin{array}{c}-1.18 \\
{[0.238]}\end{array}$ & $\begin{array}{c}-1.18 \\
{[0.238]}\end{array}$ & $\begin{array}{c}-1.18 \\
{[0.238]}\end{array}$ & $\begin{array}{c}-1.18 \\
{[0.238]}\end{array}$ & $\begin{array}{c}-1.18 \\
{[0.238]}\end{array}$ \\
\hline \multicolumn{2}{|l|}{ AR (2) } & $\begin{array}{c}0.93 \\
{[0.354]}\end{array}$ & $\begin{array}{c}0.93 \\
{[0.354]}\end{array}$ & $\begin{array}{c}0.93 \\
{[0.354]}\end{array}$ & $\begin{array}{c}0.93 \\
{[0.353]}\end{array}$ & $\begin{array}{c}0.93 \\
{[0.353]}\end{array}$ & $\begin{array}{c}0.93 \\
{[0.354]}\end{array}$ \\
\hline \multicolumn{2}{|l|}{ N. of Instruments } & 13 & 13 & 13 & 14 & 14 & 14 \\
\hline \multicolumn{2}{|l|}{ Nobs } & 1770 & 1770 & 1770 & 1770 & 1770 & 1770 \\
\hline \multicolumn{2}{|c|}{$\begin{array}{c}\text { Sargan Test } \\
\text { (Overid. Restrictions Test) }\end{array}$} & $\begin{array}{c}4.02 \\
{[0.674]}\end{array}$ & $\begin{array}{c}4.07 \\
{[0.667]}\end{array}$ & $\begin{array}{c}3.83 \\
{[0.699]}\end{array}$ & $\begin{array}{c}3.82 \\
{[0.701]}\end{array}$ & $\begin{array}{c}4.02 \\
{[0.674]}\end{array}$ & $\begin{array}{c}3.64 \\
{[0.726]}\end{array}$ \\
\hline \multicolumn{2}{|c|}{$\begin{array}{c}\text { Hansen Test } \\
\text { (Overid. Restrictions Test) }\end{array}$} & $\begin{array}{c}4.73 \\
{[0.354]}\end{array}$ & $\begin{array}{c}4.76 \\
{[0.575]}\end{array}$ & $\begin{array}{c}4.57 \\
{[0.599]}\end{array}$ & $\begin{array}{c}4.46 \\
{[0.614]}\end{array}$ & $\begin{array}{c}4.75 \\
{[0.576]}\end{array}$ & $\begin{array}{c}4.44 \\
{[0.617]}\end{array}$ \\
\hline \multirow{2}{*}{ GMM Instruments for levels } & Hansen & $\begin{array}{c}4.62 \\
{[0.328]}\end{array}$ & $\begin{array}{c}4.68 \\
{[0.321]}\end{array}$ & $\begin{array}{c}4.45 \\
{[0.348]}\end{array}$ & $\begin{array}{c}4.41 \\
{[0.353]}\end{array}$ & $\begin{array}{c}4.69 \\
{[0.321]}\end{array}$ & $\begin{array}{c}4.38 \\
{[0.357]}\end{array}$ \\
\hline & Difference & $\begin{array}{c}0.10 \\
{[0.949]}\end{array}$ & $\begin{array}{c}4.76 \\
{[0.575]}\end{array}$ & $\begin{array}{c}0.12 \\
{[0.941]}\end{array}$ & $\begin{array}{c}0.05 \\
{[0.975]}\end{array}$ & $\begin{array}{c}0.06 \\
{[0.970]}\end{array}$ & $\begin{array}{c}0.06 \\
{[0.969]}\end{array}$ \\
\hline \multirow{2}{*}{$\begin{array}{c}\text { gmmgdppercapita, collapse } \\
\text { lag (2 4) }\end{array}$} & Hansen & $\begin{array}{c}2.62 \\
{[0.270]}\end{array}$ & $\begin{array}{c}2.62 \\
{[0.270]}\end{array}$ & $\begin{array}{c}2.56 \\
{[0.278]}\end{array}$ & $\begin{array}{c}2.61 \\
{[0.271]}\end{array}$ & $\begin{array}{c}2.58 \\
{[0.275]}\end{array}$ & $\begin{array}{c}2.62 \\
{[0.269]}\end{array}$ \\
\hline & Difference & $\begin{array}{c}2.11 \\
{[0.715]}\end{array}$ & $\begin{array}{c}2.14 \\
{[0.711]}\end{array}$ & $\begin{array}{c}2.01 \\
{[0.733]}\end{array}$ & $\begin{array}{c}1.85 \\
{[0.763]}\end{array}$ & $\begin{array}{c}2.17 \\
{[0.705]}\end{array}$ & $\begin{array}{c}1.82 \\
{[0.769]}\end{array}$ \\
\hline \multirow{2}{*}{$\begin{array}{c}\text { gmmexchangerate, collapse } \\
\text { lag (24) }\end{array}$} & Hansen & $\begin{array}{c}1.17 \\
{[0.557]}\end{array}$ & $\begin{array}{c}1.17 \\
{[0.557]}\end{array}$ & $\begin{array}{c}1.09 \\
{[0.580]}\end{array}$ & $\begin{array}{c}0.99 \\
{[0.610]}\end{array}$ & $\begin{array}{c}1.30 \\
{[0.523]}\end{array}$ & $\begin{array}{c}1.00 \\
{[0.607]}\end{array}$ \\
\hline & Difference & $\begin{array}{c}3.56 \\
{[0.470]}\end{array}$ & $\begin{array}{c}3.56 \\
{[0.470]}\end{array}$ & $\begin{array}{c}{\left[\begin{array}{c}0.48 \\
3.480]\end{array}\right]} \\
{[0.480]}\end{array}$ & 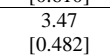 & $\begin{array}{c}3.45 \\
{[0.485]}\end{array}$ & $\begin{array}{c}3.44 \\
{[0.487]}\end{array}$ \\
\hline \multirow{2}{*}{$\begin{array}{c}\text { iv } \\
\text { other variables }\end{array}$} & Hansen & $\begin{array}{c}2.28 \\
{[0.321]}\end{array}$ & $\begin{array}{c}2.28 \\
{[0.321]}\end{array}$ & $\begin{array}{c}1.01 \\
{[0.604]}\end{array}$ & $\begin{array}{c}0.12 \\
{[0.731]}\end{array}$ & $\begin{array}{c}0.45 \\
{[0.503]}\end{array}$ & $\begin{array}{c}0.02 \\
{[0.898]}\end{array}$ \\
\hline & Difference & $\begin{array}{c}2.45 \\
{[0.654]}\end{array}$ & $\begin{array}{c}2.45 \\
{[0.654]}\end{array}$ & $\begin{array}{c}3.57 \\
{[0.468]}\end{array}$ & $\begin{array}{c}4.35 \\
{[0.501]}\end{array}$ & $\begin{array}{c}4.30 \\
{[0.507]}\end{array}$ & $\begin{array}{c}4.43 \\
{[0.490]}\end{array}$ \\
\hline
\end{tabular}

Note: $*, * *, * * *$ symbols stands for $\% 10, \% 5$ and $\% 1$ significance level respectively, statistics in square parentheses [] stands for p-values.

On the other side, base model findings indicate that foreign investors do not mainly consider the political environment of host countries in their investment decision process. There is no statistically significant relationship between the democratization level and FDI. It is also the same for political rights and civil liberties. Therefore, the decision of foreign investors might mainly depend on economic dynamics related to them and host countries 
rather than politics. However, terrorism is a determinative factor in this process due to its economic impacts on profitability and the economic environment. According to the findings, terrorism hinders FDI. However, it is only valid for the economic costs of terrorist attacks rather than the human cost dimension. Results indicate that rises in property damage levels of terrorist attacks affect the FDI ten times more than the total number of terrorist incidents. With a $10 \%$ rise in property damage due to terrorist attacks, foreign direct investment inwards decrease by $1 \%$. Also, foreign direct investment decisions are not related to the human cost of terrorist attacks. Finally, at the development level, these restriction effects of terrorism on FDI only occur in developed countries rather than underdeveloped countries.

Table: 4

Regression Results - Alternative Base Models (System GMM Twostep)

\begin{tabular}{|c|c|c|c|c|c|c|c|}
\hline \multicolumn{2}{|l|}{$\begin{array}{c}118 \text { Countries } \\
2002-2017\end{array}$} & $\begin{array}{l}\text { Model } \\
(7)\end{array}$ & $\begin{array}{c}\text { Model } \\
(8)\end{array}$ & $\begin{array}{c}\text { Model } \\
(9)\end{array}$ & $\begin{array}{c}\text { Model } \\
(10)\end{array}$ & $\begin{array}{c}\text { Model } \\
(11)\end{array}$ & $\begin{array}{c}\text { Model } \\
(12)\end{array}$ \\
\hline \multicolumn{2}{|l|}{ CREDITGDP } & 0.005 & 0.005 & 0.005 & 0.005 & 0.006 & 0.006 \\
\hline \multicolumn{2}{|c|}{ GDPPERCAPITA } & $0.00009 * * *$ & $0.00009 * * *$ & $0.0009^{* * * *}$ & $0.0009^{* * * *}$ & $0.0008 * * *$ & $0.0008^{* * * *}$ \\
\hline \multicolumn{2}{|c|}{ EXCHANGERATE } & $0.0005 * *$ & $0.0005^{* *}$ & $0.0005^{* * *}$ & $0.0005 * *$ & $0.005 * *$ & $0.005^{* * *}$ \\
\hline \multicolumn{2}{|c|}{ OPENNESS } & $0.04 * * *$ & $0.04 * * *$ & $0.05 * * *$ & $0.05 * * *$ & $0.04 * * *$ & $0.04 * * *$ \\
\hline \multicolumn{2}{|l|}{ D.PR } & 0.27 & & 0.27 & & 0.28 & \\
\hline \multicolumn{2}{|l|}{ D.CL } & & 0.05 & & 0.04 & & 0.06 \\
\hline \multicolumn{2}{|l|}{ TERROR ${ }_{I N C I D E N T S}$} & $-0.001 *$ & $-0.001 *$ & & & & \\
\hline \multicolumn{2}{|c|}{ D.TERROR CASUALTIES } & & & 0.00002 & 0.00002 & & \\
\hline \multicolumn{2}{|c|}{ TERROR PROPERTY } & & & & & $-0.01 * *$ & $-0.01 * *$ \\
\hline \multicolumn{2}{|l|}{ cons. (c) } & -0.14 & -0.14 & -0.21 & -0.21 & -0.14 & -0.14 \\
\hline \multicolumn{2}{|l|}{$\mathrm{AR}(1)$} & $\begin{array}{c}-1.18 \\
{[0.238]}\end{array}$ & $\begin{array}{c}-1.18 \\
{[0.238]}\end{array}$ & $\begin{array}{c}-1.18 \\
{[0.238]}\end{array}$ & $\begin{array}{c}-1.18 \\
{[0.238]}\end{array}$ & $\begin{array}{c}-1.18 \\
{[0.238]}\end{array}$ & $\begin{array}{c}-1.18 \\
{[0.238]}\end{array}$ \\
\hline \multicolumn{2}{|l|}{ AR (2) } & $\begin{array}{c}0.93 \\
{[0.354]}\end{array}$ & $\begin{array}{c}0.93 \\
{[0.354]}\end{array}$ & $\begin{array}{c}0.93 \\
{[0.354]}\end{array}$ & $\begin{array}{c}0.93 \\
{[0.354]}\end{array}$ & $\begin{array}{c}0.93 \\
{[0.354]}\end{array}$ & $\begin{array}{c}0.93 \\
{[0.354]}\end{array}$ \\
\hline \multicolumn{2}{|c|}{ N. of Instruments } & 13 & 13 & 13 & 13 & 13 & 13 \\
\hline \multicolumn{2}{|l|}{ Nobs } & 1770 & 1770 & 1770 & 1770 & 1770 & 1770 \\
\hline \multicolumn{2}{|c|}{$\begin{array}{c}\text { Sargan Test } \\
\text { (Overid. Restrictions Test) }\end{array}$} & $\begin{array}{c}4.08 \\
{[0.666]}\end{array}$ & $\begin{array}{c}4.02 \\
{[0.674]}\end{array}$ & $\begin{array}{c}4.13 \\
{[0.659]}\end{array}$ & $\begin{array}{c}4.08 \\
{[0.666]}\end{array}$ & $\begin{array}{c}3.89 \\
{[0.691]}\end{array}$ & $\begin{array}{c}3.84 \\
{[0.698]}\end{array}$ \\
\hline \multicolumn{2}{|c|}{$\begin{array}{c}\text { Hansen Test } \\
\text { (Overid. Restrictions Test) }\end{array}$} & $\begin{array}{c}4.86 \\
{[0.562]}\end{array}$ & $\begin{array}{c}4.88 \\
{[0.559]}\end{array}$ & $\begin{array}{c}4.89 \\
{[0.558]}\end{array}$ & $\begin{array}{c}4.91 \\
{[0.555]}\end{array}$ & $\begin{array}{c}4.70 \\
{[0.582]}\end{array}$ & $\begin{array}{c}4.74 \\
{[0.577]}\end{array}$ \\
\hline \multirow{2}{*}{ GMM Instruments for levels } & Hansen & $\begin{array}{c}4.75 \\
{[0.314]}\end{array}$ & $\begin{array}{c}4.78 \\
{[0.311]}\end{array}$ & $\begin{array}{c}4.81 \\
{[0.307]}\end{array}$ & $\begin{array}{c}4.83 \\
{[0.305]}\end{array}$ & $\begin{array}{c}4.58 \\
{[0.333]}\end{array}$ & $\begin{array}{c}4.62 \\
{[0.329]}\end{array}$ \\
\hline & Difference & $\begin{array}{c}0.11 \\
{[0.948]}\end{array}$ & $\begin{array}{c}0.11 \\
{[0.948]}\end{array}$ & $\begin{array}{c}0.08 \\
{[0.961]}\end{array}$ & $\begin{array}{c}0.08 \\
{[0.962]}\end{array}$ & $\begin{array}{c}0.12 \\
{[0.940]}\end{array}$ & $\begin{array}{c}0.13 \\
{[0.938]}\end{array}$ \\
\hline \multirow{2}{*}{$\begin{array}{c}\text { gmmgdppercapita, collapse } \\
\text { lag (24) }\end{array}$} & Hansen & $\begin{array}{c}2.74 \\
{[0.255]}\end{array}$ & $\begin{array}{c}2.81 \\
{[0.246]}\end{array}$ & $\begin{array}{c}2.74 \\
{[0.254]}\end{array}$ & $\begin{array}{c}2.81 \\
{[0.245]}\end{array}$ & $\begin{array}{c}2.68 \\
{[0.262]}\end{array}$ & $\begin{array}{c}2.77 \\
{[0.251]}\end{array}$ \\
\hline & Difference & $\begin{array}{c}2.12 \\
{[0.714]}\end{array}$ & $\begin{array}{c}2.07 \\
{[0.722]}\end{array}$ & $\begin{array}{c}2.15 \\
{[0.709]}\end{array}$ & $\begin{array}{c}2.10 \\
{[0.717]}\end{array}$ & $\begin{array}{c}2.02 \\
{[0.732]}\end{array}$ & $\begin{array}{c}1.98 \\
{[0.740]}\end{array}$ \\
\hline \multirow{2}{*}{$\begin{array}{c}\text { gmmexchangerate, collapse } \\
\text { lag (24) }\end{array}$} & Hansen & $\begin{array}{c}1.17 \\
{[0.556]}\end{array}$ & $\begin{array}{c}1.29 \\
{[0.525]}\end{array}$ & $\begin{array}{c}1.20 \\
{[.0549]}\end{array}$ & $\begin{array}{c}1.32 \\
{[0.517]}\end{array}$ & $\begin{array}{c}1.09 \\
{[0.579]}\end{array}$ & $\begin{array}{c}1.19 \\
{[0.552]}\end{array}$ \\
\hline & Difference & $\begin{array}{c}3.68 \\
{[0.451]}\end{array}$ & $\begin{array}{c}3.60 \\
{[0.463]}\end{array}$ & $\begin{array}{c}3.69 \\
{[0.450]}\end{array}$ & $\begin{array}{c}3.59 \\
{[0.464]}\end{array}$ & $\begin{array}{c}3.61 \\
{[0.461]}\end{array}$ & $\begin{array}{c}3.55 \\
{[0.470]}\end{array}$ \\
\hline \multirow{2}{*}{$\begin{array}{c}\text { iv } \\
\text { other variables }\end{array}$} & Hansen & $\begin{array}{c}1.34 \\
{[0.511]}\end{array}$ & $\begin{array}{c}2.01 \\
{[0.366]}\end{array}$ & $\begin{array}{c}1.58 \\
{[0.453]}\end{array}$ & $\begin{array}{c}1.24 \\
{[0.538]}\end{array}$ & $\begin{array}{c}1.02 \\
{[0.601]}\end{array}$ & $\begin{array}{c}0.44 \\
{[0.804]}\end{array}$ \\
\hline & Difference & $\begin{array}{c}3.51 \\
{[0.476]}\end{array}$ & $\begin{array}{c}2.87 \\
{[0.580]}\end{array}$ & $\begin{array}{c}3.31 \\
{[0.508]}\end{array}$ & $\begin{array}{c}3.67 \\
{[0.452]}\end{array}$ & $\begin{array}{c}3.69 \\
{[0.450]}\end{array}$ & $\begin{array}{c}4.31 \\
{[0.366]}\end{array}$ \\
\hline
\end{tabular}

Note: *,**,*** symbols stands for $\% 10, \% 5$ and $\% 1$ significance level respectively, statistics in square parentheses [] stands for p-values.

\subsection{Robustness Check}

The findings do not change when considering political and civil liberties as an alternative to democracy. The alternative model findings in Table 4 also show no statistically significant relationship between political rights, civil liberties, and FDI inwards. There is no change in other economic and political variables; therefore, the findings appear to be robust. 


\section{Conclusion}

In addition to direct contributions to physical capital accumulation, FDIs are seen as an important source of growth, especially for underdeveloped and developing countries, through channels such as technology transfer, innovation spread, and increased exports. It is seen that FDI currents, which started to grow in the 1980's worldwide, have reached serious volume since the 2000s. For this reason, underdeveloped and developing countries experiencing resource scarcity problems want to increase their FDI inwards. This situation requires determining the factors affecting the local and geographical distributions of FDI inwards.

When the local and geographical distributions of FDI inwards are analysed, it is seen that they started to prefer developing countries rather than developed economies, especially since the 2000s. It is widely accepted that economic factors such as cheap labour, tax advantage, and market size are behind these preferences. However, recently, political dynamics, such as democratic development level, civil liberties, political rights, and political stability, constitute a basis for intellectual property rights, can also impact FDI inwards. Indeed, foreign investors' significant and long-term investments in a country are closely related to their cost-effectiveness analysis as well as their perception of investment safety. From this point of view, it is foreseen that foreign investors will tend to prefer democratic and free countries with intellectual property rights and countries with low levels of political uncertainty and instability. Approximately $75 \%$ of the FDI inwards, realized during the 2002-2017 period, were seen to lead democratic countries; and similarly, it was seen that $70 \%$ was concentrated on countries with free status.

In this study, the effects of political factors on the geographical distribution of FDI inwards, under the sample of 118 developed and developing countries in 2002-2017, were investigated. In the wake of this study, it was found that foreign investors act only according to economic factors, and they tend to neglect political factors that are democratic development and freedom levels (civil liberties and political rights) of the countries they invest in. Furthermore, it has been found that terrorist incidents with high material damage rather than human dimension have a diverging effect on FDI inwards. It is seen that these diverting effects appear to be mostly in developed countries compared to developing ones.

From this point of view, it can be put forward that developing countries need to prioritize economic policies towards increasing international integration and liberalization, especially to attract foreign resources. Moreover, FDI inwards to any country will increase when the fight against terrorism is succeeded. In this regard, countries experiencing highlevel terrorism must establish common policies in the battle against terrorism by establishing pacts, etc. In this direction, they should handle the economic, political, social, and psychological causes of terrorism to overcome problems effectively. 


\section{References}

Abadie, A. \& J. Gardeazabal (2008), "Terrorism and the World Economy", European Economic Review, 52, 1-27.

Adams, S. (2009), "Foreign Direct Investment, Domestic Investment, and Economic Growth in SubSaharan Africa", Journal of Policy Modelling, 31, 939-949.

Akınc1, M. et al. (2015), "The Impact of Terrorism on Direct and Indirect Investments: How Much Are Foreign Aids Compensative?", AU SBF Journal, 70(1), 1-33.

Alesina, A. \& R. Perotti (1994), "The Political Economy of Growth: A Critical Survey of the Recent Literature", The World Bank Economic Review, 8(3), 351-371.

Alguacil, M. et al. (2002), "Foreign Direct Investment, Exports, and Domestic Performance in Mexico: A Causality Analysis", Economics Letters, 77(3), 371-376.

Alguacil, M. et al. (2011), "Inward FDI and Growth: The Role of Macroeconomic and Institutional Environment", Journal of Policy Modelling, 33(2011), 581-496.

Ali, H. et al. (2017), "How Terrorism Affects Foreign Direct Investment in Pakistan?", International Journal of Economics and Financial Issues, 7(3), 625-631.

Balasubramanyam, V.N. et al. (1996), "Foreign Direct Investment and Growth in EP and is Countries", The Economic Journal, 106(434), 92-105.

Baldwin, R. et al. (2005), "Multinationals, Endogenous Growth, and Technological Spillovers: Theory and Evidence", Review of International Economics, 13(5), 945-963.

Bandyopadhyay, S. et al. (2011), "Foreign Direct Investment, Aid, and Terrorism: An Analysis of Developing Countries", Federal Reserve Bank of St. Louis Working Paper No. 2011.

Bandyopadhyay, S. et al. (2014), "Foreign Direct Investment, Aid, and Terrorism", Oxford Economic Papers, 66(1), 25-50.

Berthelemy, J-C \& S. Demurge (2000), "Foreign Direct Investment and Economic Growth: Theory and Application to China", Review of Development Economics, 4(2), 140-155.

Bezic, H. et al. (2016), "The Impact of Terrorism on the FDI of the EU and EEA Countries", Zbornik radova Ekonomskog fakulteta u Rijeci: časopis za ekonomsku teoriju i praksu, 34(2), 333-362.

Blomberg, S.B. \& A. Mody (2005), "How Severely Does Violence Deter International Investment?", Claremont Colleges Working Papers No.2005-01.

Blume, L. \& S. Voigt (2007), “The Economic Effects of Human Rights”, Kyklos, 60(4), 509-538.

Borensztein, E. et al. (1998), "How Does Foreign Direct Investment Affect Economic Growth?", Journal of International Economics, 45(1), 115-135.

Bronzini, R. \& P. Piselli (2009), "Determinants of Long-Run Regional Productivity with Geographical Spillovers: The Role of R\&D, Human Capital and Public Infrastructure", Regional Science and Urban Economics, 39(2009), 187-199.

Busse, M. (2003), "Democracy and FDI”, HWWA Discussion Paper No.220.

Caballero, R.J. \& R. Pindyck (1992), “Uncertainty, Investment, and Industry Evolution”, National Bureau of Economic Research WPNo.4380.

Çelik, N. \& M. Karaçuka (2018), "Bölgesel Kalkınmanın İktisadi Politiği: Siyasal Çoğulculuk ve Yatırım İlişkisi”, Sosyoekonomi, 26(37), 243-255. 
Cervellati, M. \& U. Sunde (2011), “Democratization, Violent Social Conflicts, and Growth”, IZA DP No. 5643.

Choe, J.I. (2003), "Do Foreign Direct Investment and Gross Domestic Investment Promote Economic Growth?", Review of Development Economics,7(1), 44-57.

Cuadros, A. et al. (2004), "Openness and Growth: Re-Examining Foreign Direct Investment, Trade and Output Linkages in Latin America", The Journal of Development Studies, 40(4), 167-192.

Daniele, V. \& U. Marani (2011), "Organized Crime, the Quality of Local Institutions and FDI in Italy: A Panel Data Analysis”, European Journal of Political Economy, 27, 132-142.

De Haan, J. \& C.L.J. Siermann (1996), "New Evidence on the Relationship between Democracy and Economic Growth", Public Choice, 86(1-2), 175-198.

De Mello, L.R. (1999), "Foreign Direct Investment-led Growth: Evidence from Time Series and Panel Data”, Oxford Economic Papers, 51, 133-151.

Dunning, J.H. (1993), Multinational Enterprises and the Global Economy, UK: Edward Elgar Publishing Company.

Efobi, U. et al. (2018), “Aid, Terrorism, and Foreign Direct Investment: Empirical Insight Conditioned on Corruption Control", International Economic Journal, 32(4), 610-630.

Enders, W. \& T. Sandler (1996), "Terrorism and Foreign Direct Investment in Spain and Greece", Kyklos, 49(3), 331-352.

Enders, W. et al. (2006), "The Impact of Transnational Terrorism on US Foreign Direct Investment", Political Research Quarterly, 59(4), 517-531.

Fedderke, J.W. \& A.T. Romm (2006), "Growth Impact and Determinants of Foreign Direct Investment into South Africa, 1956-2003”, Economic Modelling, 23, 738-760.

Feng, Y. (1997), “Democracy, Political Stability, and Economic Growth”, British Journal of Political Science, 27(3), 391-418.

Filer, R.K. \& D. Stanisic (2016), "The Effect of Terrorist Incidents on Capital Flows", Review of Development Economics, 20(2), 502-513.

Freedom House (2018), "Democracy in Crisis", Freedom in the World 2018 Report.

Global Business Policy Council (2004), FDI Confidence Index, A.T. Kearney, Alexandria, Virginia.

Goh, S.K. et al. (2017), "Re-Examining Foreign Direct Investment, Exports, and Economic Growth in Asian Economies Using a Bootstrap ARDL Test for Cointegration", Journal of Asian Economics, 51, 12-22.

Grier, K.B. \& G. Tullock (1989), “An Empirical Analysis of Cross-National Economic Growth 1951-80”, Journal of Monetary Economics, 24(2), 259-276.

Gujarati, D.N. \& D.C. Porter (2012), Basic Econometrics, İstanbul: Literatür Publication.

Gupta, D.K. et al. (1998), "Democracy, Economic Growth, and Political Instability: An Integrated Perspective", The Journal of Socio-Economics, 27(5), 587-589.

Helliwell, J.F. (1994), "Empirical Linkages between Democracy and Economic Growth", British Journal of Political Science, 24(2), 225-248.

Iamsiraroj, S. \& M.A. Ulubaşoğlu (2015), "Foreign Direct Investment and Economic Growth: A Real Relationship or Wishful Thinking?”, Economic Modelling, 51, 200-213. 
IEP (2017), Global Terrorism Index 2017 Measuring and Understanding the Impact of Terrorism, Institute for Economics \& Peace.

Javorcik, B.S. (2004), "Does Foreign Direct Investment Increase the Productivity of Domestic Firms? In Search of Spillovers through Backward Linkages", American Economic Association, 94(3), 605-627.

Jensen, N.M. (2003), "Democratic Governance and Multinational Corporations: Political Regimes and Inflows of Foreign Direct Investment", International Organization, 57(3), 587-616.

Kang, S.J. \& H.S. Lee (2007), “Terrorism and FDI Flows Cross-country Dynamic Panel Estimation”, Journal of Economic Theory and Econometrics, 18(1), 57-77.

Kinyanjui, S. (2014), "The Impact of Terrorism on Foreign Direct Investment in Kenya", International Journal of Business Administration, 5(3), 148-157.

Knutsen, C.H. (2013), "Democracy, State Capacity, and Economic Growth", World Development, $43,1-18$.

Kottaridi, C. \& T. Stengos (2010), "Foreign Direct Investment, Human Capital, and Non-Linearities in Economic Growth", Journal of Macroeconomics, 32, 858-871.

Kunimitsu, Y. (2005), Direct and Indirect Effects of Public Infrastructure on Regional Economic Growth in Japan: An Application of the Covariance Structure Model by Geographical Classification Area, (No. 1365-2016-108126).

Kurzman, C.R. et al. (2002), "Democracy's Effect on Economic Growth: A Pooled Time-Series Analysis 1951-1980", Studies in Comparative International Development, 37(1), 3-33.

Leblang, D.A. (1996), "Property Rights, Democracy and Economic Growth", Political Research Quarterly, 49(1), 5-26.

Liu, Z. (2008), "Foreign Direct Investment and Technology Spillovers: Theory and Evidence", Journal of Development Economics, 85(1-2), 176-193.

Lutz, J.M. \& B.J. Lutz (2006), "International Terrorism in Latin America: Effects on Foreign Investment and Tourism", Journal of Economic, Social and Political Studies, 31, 321338.

Makki, S. \& A. Somwaru (2004), "Impact of Foreign Direct Investment and Trade on Economic Growth: Evidence from Developing Countries", American Journal of Agricultural Economics, 86(3), 795-801.

Marshall, M.G. et al. (2013), Polity IV Project Political Regime Characteristics and Transitions, 1880-2012, Center for Systemic Peace, April 2013.

Mbaku, J.M. \& M.S. Kimenyi (1997), "Macroeconomic Determinants of Growth: Further Evidence on the Role of Political Freedom", Journal of Economic Development, 22(2), 119-132.

Mistura, F. \& C. Roulet (2019), "The Determinants of Foreign Direct Investment: Do Statutory Restrictions Matter?", OECD Working Papers on International Investment 2019/01.

Moosa, I.A. (2002), FDI: Theory, Evidence, and Practice, New York: Palgrave.

Narayan, P.K. et al. (2011), "Does Democracy Facilitate Economic Growth or Does Economic Growth Facilitate Democracy? An Empirical Study of Sub-Saharan Africa", Economic Modelling, 28(3), 900-910.

Nitsch, V. \& D. Schumacher (2004), “Terrorism and International Trade: An Empirical Investigation”, European Journal of Political Economy, 20(2), 423-433. 
OECD (2019), “The determinants of Foreign Direct Investment: Do statutory restrictions matter?”, OECD Working Papers on International Investment 2019/01.

Önder, A.Ö. et al. (2010), "The Impact of Public Capital Stock on Regional Convergence in Turkey", European Planning Studies, 18(7), 1041-1055.

Özler, S. \& D. Rodrick (1992), "External Shocks, Politics and Private Investment: Some Theory and Empirical Evidence", NBER Working Paper 3960, 1-25.

Papaioannou, E. \& G. Siourounis (2008), "Democratization and Growth", The Economic Journal, $118(532), 1520-1551$.

Papanek, G.V. (1973), “Aid, Foreign Private Investment, Savings and Growth in Less Developed Countries", The Journal of Political Economy, 81(1), 120-130.

Pereira, A.M. \& O. Roca-Sagalés (2003), "Spillover Effects of Public Capital Formation: Evidence from the Spanish Regions", Journal of Urban Economics, 53(2), 238-256.

Pindyck, R.S. (1991), "Irreversibility, Uncertainty, and Investment”, Journal of Economic Literature, 29, 1110-1148.

Powers, M. \& S.W. Choi (2012), "Does Transnational Terrorism Reduce Foreign Direct Investment? Business-Related versus Non-Business-Related Terrorism”, Journal of Peace Research, 49(3), 407-422.

Qureshi, A. et al. (2015), "Democracy, Regime Stability, and Economic Growth: A Cross Country Dynamic Panel Data Analysis", Journal of Economics and Sustainable Development, 6(12), 23-44.

Roodman, D. (2009), 'How to Do xtabond2: An Introduction to 'Difference' and 'System' GMM in Stata", Stata Journal, 9(1), 86-136.

Saeed, A. et al. (2018), "Taxing Impact of Terrorism on Global Economic Openness of Developed and Developing Countries", Acta Oeconomica, 68(3), 311-335.

Schneider, F. \& B. Frey (1985), "Economic and Political Determinants of Foreign Direct Investment", World Development, 13, 161-175.

Scully, G.W. (1988), “The Institutional Framework and Economic Development”, Journal of Political Economy, 96(3), 652-662.

Shahbaz, M.A. et al. (2013), "Impact of Terrorism on Foreign Direct Investment in Pakistan", Archives of Business Research, 1(1), 1-7.

Shioji, E. (2001), "Public Capital and Economic Growth: A Convergence Approach", Journal of Economic Growth, 6, 205-227.

Sunde T. (2017), "Foreign Direct Investment, Exports, and Economic Growth: ADRL and Causality Analysis for South Africa", Research in International Business and Finance, 41, 434-44.

Ullah, I. \& M. Rehman (2014), "Terrorism and Foreign Direct Investments in Pakistan: A Cointegration Analysis", Journal of Economics and Sustainable Development, 5(15), 233-242.

UNCTAD (2004), World Investment Report, United Nations Conference for Trade and Development, Geneva.

Wang, E.C. (2002), "Public Infrastructure and Economic Growth: A New Approach Applied to East Asian Economies", Journal of Policy Modelling, 24, 411-435. 
Çelik, N. \& R. Bayrak (2022), "The Linkages Between Democracy, Terrorism and Foreign Direct Investments in Developed and Developing Countries", Sosyoekonomi, 30(51), 119-136.

Zakaria, M. et al. (2019), "Effect of Terrorism on Economic Growth in Pakistan: An Empirical Analysis", Economic Research-Ekonomskaİstraživanja, 32(1), 1794-1812. 